CLINICAL STUDY

\title{
Impaired quality of life and sexual function in overweight and obese men: the European Male Ageing Study
}

Thang S Han, Abdelouahid Tajar ${ }^{1}$, Terence W O’Neill ${ }^{1}$, Min Jiang ${ }^{2}$, György Bartfai ${ }^{3}$, Steven Boonen ${ }^{4,5}$, Felipe Casanueva ${ }^{6}$, Joseph D Finn ${ }^{7}$, Gianni Forti ${ }^{8}$, Aleksander Giwercman ${ }^{9}$, Ilpo T Huhtaniemi ${ }^{10}$, Krzysztof Kula ${ }^{11}$, Neil Pendleton ${ }^{12}$, Margus Punab ${ }^{13}$, Alan J Silman ${ }^{14}$, Dirk Vanderschueren ${ }^{5,15}$, Michael E J Lean ${ }^{16}$, Frederick $\mathrm{C} W \mathrm{Wu}^{7}$ and the EMAS group

Department of Endocrinology, University College London Hospital Medical School, London, UK, ${ }^{1}$ Arthritis Research UK, Epidemiology Unit, Manchester Academic Health Science Centre, The University of Manchester, Manchester, UK, ${ }^{2}$ Department of Physiology, University of Turku, Turku, Finland, ${ }^{3}$ Department of Obstetrics, Gynaecology and Andrology, Albert Szent-György Medical University, Szeged, Hungary, ${ }^{4}$ Leuven University Division of Geriatric Medicine, Katholieke Universiteit Leuven, Leuven, Belgium, ${ }^{5}$ Leuven University Center for Metabolic Bone Diseases, Katholieke Universiteit Leuven, Leuven, Belgium, ${ }^{6}$ Department of Medicine, Santiago de Compostela University, Complejo Hospitalario Universitario de Santiago (CHUS), CIBER de Fisiopatología Obesidad y Nutricion (CBO6/03), Instituto Salud Carlos III, Santiago de Compostela, Spain, ${ }^{7}$ Department of Endocrinology, Manchester Academic Health Science Centre, Manchester Royal Infirmary, The University of Manchester, Manchester, UK, ${ }^{8}$ Andrology Unit, Department of Clinical Physiopathology, University of Florence, Florence, Italy, ${ }^{9}$ Department of Urology, Scanian Andrology Centre, Malmö University Hospital, University of Lund, Lund, Sweden, ${ }^{10}$ Department of Reproductive Biology, Imperial College London, Hammersmith Campus, London, UK, ${ }^{11}$ Department of Andrology and Reproductive Endocrinology, Medical University of Lodz, Lodz, Poland, ${ }^{12}$ Clinical Gerontology, Manchester Academic Health Science Centre, Hope Hospital, The University of Manchester, Salford, UK, ${ }^{13}$ Andrology Unit, United Laboratories of Tartu University Clinics, Tartu, Estonia, ${ }^{14}$ Arthritis Research UK, Chesterfield, UK, ${ }^{15}$ Leuven University Division of Endocrinology, Katholieke Universiteit Leuven, Leuven, Belgium and ${ }^{16}$ Department of Human Nutrition, University of Glasgow, Glasgow, Scotland, UK

(Correspondence should be addressed to T S Han; Email: t.s.han@doctors.org.uk)

\begin{abstract}
Background: Few published data link overweight and obesity with measures of quality of life (QoL) including sexual health in men.

Objective: To assess the association of overweight/obesity with impairment of physical and psychological QoL and sexual functions in men.

Design and setting: Cross-sectional, multicentre survey of 3369 community-dwelling men aged 40-79 (mean \pm s.D., 60 \pm 11 ) years randomly selected from eight European centres.

Outcomes: Adiposity was assessed by body mass index (BMI) and waist circumference (WC), QoL and functional impairments by physical and psychological function domains of the Short Form-36 questionnaire, Beck's Depression Inventory and the European Male Ageing Study sexual function questionnaire.

Results: Complete data on sexual activities and erectile function were available in $2734(92 \%)$ and 3193 $(95 \%)$ of the participants respectively. From the population studied, 814 men were obese (BMI $\geq 30 \mathrm{~kg} / \mathrm{m}^{2}$ ) and 1171 had $\mathrm{WC} \geq 102 \mathrm{~cm}, 25 \%$ of all men were unable to do vigorous activity and $2-13 \%$ reported depressive symptoms. Symptoms of sexual dysfunction ranged between 22\% (low sexual desire) and $40 \%$ (infrequent morning erections) of the participants. Among obese men with both BMI $\geq 30 \mathrm{~kg} / \mathrm{m}^{2}$ and $\mathrm{WC} \geq 102 \mathrm{~cm}$, at least one symptom of impaired physical, psychological and sexual function was reported by 41,43 and $73 \%$ of the participants respectively. Compared with the reference group of non-obese men (BMI $<30 \mathrm{~kg} / \mathrm{m}^{2}$ and WC $<102 \mathrm{~cm}$ ), men with BMI $\geq 30 \mathrm{~kg} / \mathrm{m}^{2}$ and $W C \geq 102 \mathrm{~cm}$ more frequently reported at least one symptom of impaired physical function (odds ratio $(\mathrm{OR})=2.67$; confidence interval $(\mathrm{CI})$ : 2.07-3.45, $\mathrm{P}<0.001)$, impaired psychological function $(\mathrm{OR}=1.48$; CI: $1.14-1.90, P<0.01)$ and impaired sexual function $(\mathrm{OR}=1.45 ; \mathrm{CI}: 1.14-1.85$, $P<0.01)$. These functional impairments were also more prevalent in men who had $W C \geq 102 \mathrm{~cm}$ even with BMI $<30 \mathrm{~kg} / \mathrm{m}^{2}$, but those with BMI $\geq 30 \mathrm{~kg} / \mathrm{m}^{2}$ and WC $<102 \mathrm{~cm}$ generally did not suffer from increased impaired physical or sexual health. Men with high BMI and WC were at even greater likelihood of having a composite of two or more or three or more symptoms compared with those with normal BMI and WC.

Conclusions: Men with high WC, including those who are 'non-obese' with BMI $<30 \mathrm{~kg} / \mathrm{m}^{2}$, have poor QoL with symptoms of impaired physical, psychological and sexual functions. Health promotion to improve QoL should focus on prevention of obesity and central fat accumulation.
\end{abstract}

European Journal of Endocrinology 164 1003-1011 


\section{Introduction}

Links between adverse adiposity and chronic illnesses are well documented (1), but surprisingly, little is published on its association with quality of life (QoL) including sexual health, especially in men. Overweight/obesity, indicated by high body mass index (BMI) or waist circumference (WC), has reached an epidemic proportion worldwide. Between the 1980s and the mid-2000s, the prevalence of obesity (BMI $\geq 30 \mathrm{~kg} / \mathrm{m}^{2}$ ) has approximately doubled in Europe (2), Australia (3) and the United States $(4,5)$ with no sign of abating (6), and highest rates occur among South Asians, African Americans and Hispanics as well as the socioeconomically disadvantaged (7-9). In 2002, the World Health Organization reported between 25 and $75 \%$ of European adults in both non-transitional and transitional countries to be overweight and up to $20 \%$ of men and $30 \%$ of women to be obese (10). By 2004, $66 \%$ of American adults were overweight and $32 \%$ obese (8). Over the 10 years to 1999-2000, morbid obesity (BMI $\geq 40 \mathrm{~kg} / \mathrm{m}^{2}$ ) increased from 0.8 to $2.2 \%(11)$. In Scotland, $1.4 \%$ of men and $3.5 \%$ of women reach BMI $>40 \mathrm{~kg} / \mathrm{m}^{2}$ (12). Longitudinal studies have shown that the fastest weight increases were in young adults with little increase beyond the 5th decade $(8,13)$. This pattern may change as the obesity epidemic progresses.

Obesity exerts major burdens on health care in many ways, from obviously obesity-related conditions (14-16) to the hidden costs of personal care and indirect costs associated with absenteeism, disability, premature mortality and workers' compensation (17). The health care costs of obesity extend well beyond the conventional costs of obesity-related diseases, with increased prescribing costs in almost all drug classes (18). In the United States, health care spending in 2002 for obese adults was $56 \%$ higher than that for normal-weight adults, an excess of US \$1244 per person per annum (19). Expenditure on obesity-related conditions reached US $\$ 147$ billion in 2008, representing $9.1 \%$ of all medical spending compared with $6.5 \%$ in 1998 (20), reflecting disproportionate of the most expensive drug group for a variety of conditions (18).

The present analysis of the European Male Ageing Study (EMAS) database of European Union men aged 40-79 years aims to define the extent to which a range of common 'QoL' symptoms usually attributed to ageing, including impaired physical, psychological and sexual functions, are associated with overweight/ obesity, as indicated by a high BMI and WC.

\section{Methods}

\section{Subjects and study design}

A total of 3369 men aged $40-79$ (mean \pm s.D.: $60 \pm 11$ ) years were recruited from population registers in eight
European centres, including centres from five nontransitional (Florence, Italy; Leuven, Belgium; Malmö, Sweden; Manchester, UK; Santiago de Compostela, Spain) and three transitional countries (Lodz, Poland; Szeged, Hungary; Tartu, Estonia). For the baseline survey, stratified random sampling was used with the aim of recruiting equal numbers of men in each centre and into each of four age bands $(40-49,50-59,60-69$ and 70-79 years). After completing a postal questionnaire including information about smoking habits, alcohol consumption and the presence of morbidities (hypertension, cardiovascular disease (CVD), stroke, cancer, bronchitis, asthma, peptic ulcer, epilepsy, diabetes mellitus, hepatic, renal and prostate diseases), subjects attended research clinics for a health screen as described previously (21). Each participant completed interviewer-assisted questionnaires and underwent clinical assessments including anthropometry (weight, height, WC). The questionnaires included the Short Form-36 (SF-36) health survey (22) and Beck's Depression Inventory (BDI) (23). Subjects then privately completed the EMAS sexual function questionnaire (EMAS-SFQ) (24) (Supplementary Table 1, see section on supplementary data given at the end of this article). The two physical function and psychological function domains comprising 27 dimensions from SF-36 and BDI questionnaires and the one sexual function domain comprising five dimensions were used for analysis in this study. Ethics approval for the study was obtained in accordance with local institutional requirements in each centre and participants gave informed consent.

\section{Statistical analysis}

Individuals were categorised according to their BMI $\left(<25,25-30\right.$ and BMI $\left.\geq 30 \mathrm{~kg} / \mathrm{m}^{2}\right)$ or the previously defined WC 'action levels' $(<94,94-102$ and $\geq 102 \mathrm{~cm})(25,26)$. For the purpose of this analysis, smoking status was categorised as either current or ever smoker, alcohol intake as frequent ( 5 days a week or more) and infrequent ( $<5$ days/week) drinkers and co-morbidity as none or at least one of the health problems (hypertension, heart conditions, stroke, cancer, bronchitis, asthma, peptic ulcer, epilepsy, diabetes, liver, kidney and prostate diseases).

The $\chi^{2}$ test of independence was used to assess the associations between items of impaired physical, psychological or sexual function and BMI or WC. Multivariable logistic regression analysis, with or without adjustments for potential confounding factors (age, smoking status, alcohol intake and centre), was used to estimate the likelihood of having symptoms of impaired physical, psychological and sexual functions (dependent variables) in obese men with BMI $\geq 30 \mathrm{~kg} / \mathrm{m}^{2}$ and/or WC $\geq 102 \mathrm{~cm}$ (independent variables). We decided that the results should be presented without adjusting for 'co-morbidity' because the 'co-morbidities' are in part secondary to adiposity, and we are interested in the 
overall effect of adiposity. Finally, the same regression approach was used to assess the likelihood of having at least one symptom within each of the three domains (physical, psychological or sexual function) in different groups of men classified according to their various combinations of adiposity (BMI $<30$ or $\geq 30 \mathrm{~kg} / \mathrm{m}^{2}$ and WC $<102$ or $\geq 102 \mathrm{~cm}$ ). To assess the burden of symptoms met by individuals, composites of two or more or three or more symptoms compared with none were also analysed in men across different categories of adiposity.

Robust standard errors were used to adjust for recruitment centre, which takes into account the hierarchy of the study design (individuals nested within centres). Results from the logistic regression models are expressed as odds ratios (ORs) and 95\% confidence intervals (CIs).

Receiver operating characteristic (ROC) analysis was used to evaluate the predictive power of BMI and WC on the outcomes (impaired symptoms) in the regression models. The higher the area under the curve, i.e. the greater the curvature bowing away from the $50 \%$ line (zero prediction), the greater the predictive power. All statistical analyses were conducted using Intercooled STATA version 9.2 (Stata Corp, College Station, TX, USA).

\section{Results}

A total of 3369 (mean \pm s.D. age: $60 \pm 11$ years) men participated in the EMAS study. Complete data concerning frequency of sexual activities (excluding men without a sexual partner) and erectile function were available in $2734(92 \%)$ and $3193(95 \%)$ of the participants respectively. Demographics of the EMAS sample are shown in Table 1. With regard to physical and psychological functions (Supplementary Table 2, see section on supplementary data given at the end of this article), $25 \%$ of men were unable to do vigorous activity and $2-13 \%$ reported depressive symptoms. Symptoms of impaired sexual function affected between $22 \%$ (low sexual desire), 30\% (erectile dysfunction) and $40 \%$ (infrequent morning erections) of the participants. Functional impairment in these domains was consistently more prevalent in men who had either high BMI (Table 2) or WC (Table 3). Among those who had both high BMI and high WC, 41\% had at least one impaired physical function (Fig. 1a), 43\% had at least one symptom of impaired psychological function (Fig. 1b) and $73 \%$ had at least one of the symptoms of impaired sexual function (Fig. 1c).

Multivariable logistic regression models (Table 2) show that compared with the reference group of lean men (based on BMI $<25 \mathrm{~kg} / \mathrm{m}^{2}$ ), obese men (BMI $\geq 30$ $\mathrm{kg} / \mathrm{m}^{2}$ ) were more likely to report impaired physical function (ORs range 2.2-3.3), impaired psychological function (ORs up to 2.7) and erectile dysfunction
Table 1 Characteristics of 3369 European Union men.

\begin{tabular}{lc}
\hline Characteristics & \multicolumn{1}{c}{ Values } \\
\hline Age (years; mean (s.D.)) & $60.0(11.0)$ \\
Height (cm; mean (S.D.)) & $173.6(7.3)$ \\
Weight (kg; mean (S.D.)) & $83.5(14.0)$ \\
BMI (kg/m²; mean (s.D.)) & $27.7(4.1)$ \\
Waist circumference (cm; mean (s.D.)) & $98.5(11.1)$ \\
Quality of life (SF-36) ; mean (s.D.) & \\
Physical function domain & $27.1(3.8)$ \\
Physical role domain & $17.2(3.8)$ \\
Body pain domain & $9.3(2.4)$ \\
General health domain & $17.9(4.0)$ \\
Vitality domain & $14.9(3.0)$ \\
Social function domain & $8.9(1.5)$ \\
Emotion domain & $13.4(2.5)$ \\
Mental domain & $20.3(3.5)$ \\
Depressive symptoms (BDI) ${ }^{\text {b. }}$ mean (s.D.) & $7.0(6.5)$ \\
BMl $n(\%)$ & \\
$\geq 25$ and $<30 \mathrm{~kg} / \mathrm{m}^{2 \mathrm{c}}$ & $1629(49.2)$ \\
$\geq 30 \mathrm{~kg} / \mathrm{m}^{2}$ & $814(24.6)$ \\
Waist circumference $n(\%)$ & \\
$\geq 94$ and $<102 \mathrm{~cm}^{\mathrm{c}}$ & $1006(30.3)$ \\
$\geq 102 \mathrm{~cm}$ & $1171(35.3)$ \\
Current smokers $(n(\%))$ & $705(21.1)$ \\
Alcohol intake $\geq 5$ days/week $(n(\%))$ & $762(22.8)$ \\
\hline
\end{tabular}

${ }^{\mathrm{a}}$ Higher scores indicate better quality of life.

b Lower scores indicate greater depressive symptoms.

${ }^{5} 56$ men had missing BMI data and 50 men had missing waist circumference data. The remaining men with $\mathrm{BMI}<25 \mathrm{~kg} / \mathrm{m}^{2}$ were 870 and waist circumference $<94$ were 1142 .

(OR 1.8, 95\% CI: 1.4-2.3). Similar patterns emerged in men with high $W C(\geq 102 \mathrm{~cm})$ (Table 3$)$.

The symptoms from the three domains found to be associated with BMI and/or WC were further analysed in different categories of obese men and non-obese men to explore potential interaction effects of BMI and WC (Table 4). Compared with the reference group of nonobese men (BMI $<30 \mathrm{~kg} / \mathrm{m}^{2}$ and $W C<102 \mathrm{~cm}$ ), men with BMI $\geq 30 \mathrm{~kg} / \mathrm{m}^{2}$ and WC $\geq 102 \mathrm{~cm}$ were more likely to have symptoms of impaired physical and psychological function and more likely to have erectile dysfunction. These relationships persisted, only slightly less strongly, even in men with WC $\geq 102 \mathrm{~cm}$ but BMI $<30 \mathrm{~kg} / \mathrm{m}^{2}$. By contrast, apart from tiredness, generally there was no increased risk in these health impairments in men with high BMI but with WC $<102 \mathrm{~cm}$ (Table 4). All the above relationships were independent of age and lifestyle factors.

Finally multivariable logistic regression was used to test the association between the presence of at least one symptom or composites of two or more and three or more symptoms within each of the three domains in men with adverse adiposity (Tables 2-4). Different combinations of groups of men with varying degrees of obesity (BMI $<30$ or $\geq 30 \mathrm{~kg} / \mathrm{m}^{2}$ and WC $<102$ or $\geq 102 \mathrm{~cm}$ ) were used as independent variable. Table 4 shows that compared with the reference group of nonobese men (BMI $<30 \mathrm{~kg} / \mathrm{m}^{2}$ and WC $<102 \mathrm{~cm}$ ), obese men with BMI $\geq 30 \mathrm{~kg} / \mathrm{m}^{2}$ and WC $\geq 102 \mathrm{~cm}$ had higher likelihood of reporting at least one symptom of 
Table 2 Prevalence and odds ratios to estimate the risk of symptoms from three domains of physical function (Short Form-36, SF-36), psychological function (SF-36 and Beck's Depression Inventory (BDI)) and sexual symptoms (European Male Ageing Study sexual function questionnaire, EMAS-SFQ) in different categories of body mass index (BMI).

\begin{tabular}{|c|c|c|c|c|c|c|}
\hline & \multicolumn{3}{|c|}{ BMI $\left(\mathrm{kg} / \mathrm{m}^{2} ; n(\%)\right)$} & \multirow[b]{2}{*}{$\chi^{2}$ test $^{b}$} & \multicolumn{2}{|c|}{ BMI $\left(\mathrm{kg} / \mathrm{m}^{2} ; \text { OR }(95 \% \mathrm{Cl})\right)^{\mathrm{a}}$} \\
\hline & $<25$ & $\geq 25$ and $<30$ & $\geq 30$ & & $\geq 25$ and $<30$ & $\geq 30$ \\
\hline \multicolumn{7}{|l|}{ Physical function } \\
\hline Unable to do vigorous activity & $164(19.0)$ & $376(23.3)$ & $275(34.0)$ & $<0.001$ & $1.18(0.92,1.53)$ & $2.23(1.59,3.13)^{\ddagger}$ \\
\hline Unable to do moderate activity & $24(2.8)$ & $49(3.0)$ & $30(3.7)$ & 0.51 & $0.89(0.39,2.00)$ & $1.20(0.79,1.80)$ \\
\hline Unable to carry heavy weights & $23(2.7)$ & $38(2.4)$ & $34(4.2)$ & 0.03 & $0.78(0.39,1.54)$ & $1.53(0.68,3.42)$ \\
\hline Unable to climb one flight of stairs & $15(1.7)$ & $25(1.6)$ & $19(2.4)$ & 0.37 & $0.81(0.47,1.42)$ & $1.29(0.59,2.80)$ \\
\hline Unable to climb several flights of stairs & $41(4.8)$ & $109(6.7)$ & $98(12.1)$ & $<0.001$ & $1.38(0.87,2.17)$ & $2.85(1.76,4.63)^{\ddagger}$ \\
\hline Unable to bend & $32(3.7)$ & $87(5.4)$ & $93(11.5)$ & $<0.001$ & $1.34(0.74,2.40)$ & $3.27(1.80,5.95)^{\ddagger}$ \\
\hline Unable to feeding yourself & $13(1.5)$ & $16(1.0)$ & $17(2.1)$ & 0.08 & $0.59(0.25,1.37)$ & $1.30(0.55,3.07)$ \\
\hline Unable to rise from a chair & $10(1.2)$ & $14(0.9)$ & $13(1.6)$ & 0.26 & $0.67(0.21,2.16)$ & $1.20(0.59,2.44)$ \\
\hline Unable to walk in your home & $10(1.2)$ & $10(0.6)$ & $7(0.9)$ & 0.36 & $0.49(0.22,1.09)$ & $0.59(0.27,1.32)$ \\
\hline Unable to bath yourself & $10(1.2)$ & 21 (1.3) & $9(1.1)$ & 0.91 & $0.98(0.51,1.85)$ & $0.90(0.38,2.17)$ \\
\hline Unable to walk more than $1 \mathrm{~km}$ & 37 (4.3) & $112(6.9)$ & 91 (11.3) & $<0.001$ & $1.62(0.93,2.84)$ & $2.99(2.05,4.36)^{\ddagger}$ \\
\hline Reduced work & $37(4.3)$ & $73(4.5)$ & $71(8.8)$ & $<0.001$ & $1.08(0.68,1.72)$ & $2.30(1.22,4.34)^{\ddagger}$ \\
\hline$\geq 1$ impaired physical function & $182(21.3)$ & $410(26.0)$ & $311(39.4)$ & $<0.001$ & $1.22(0.93,1.58)$ & $2.56(1.87,3.50)^{\ddagger}$ \\
\hline$\geq 2$ impaired physical function & $68(8.0)$ & $188(11.9)$ & $153(19.4)$ & $<0.001$ & $1.55(1.00,2.39)^{\star}$ & $3.57(2.36,5.40)^{\ddagger}$ \\
\hline$\geq 3$ impaired physical function & $49(5.7)$ & $95(6.0)$ & $96(12.2)$ & $<0.001$ & $1.05(0.64,1.73)$ & $3.13(1.92,5.09)^{\ddagger}$ \\
\hline \multicolumn{7}{|l|}{ Psychological function } \\
\hline Down in the dumps & $25(2.9)$ & $40(2.5)$ & $29(3.6)$ & 0.30 & $0.86(0.6$ & $1.32(0.90,1.93)$ \\
\hline Full of life & $94(11.0)$ & $156(9.7)$ & $94(11.7)$ & 0.27 & $0.83(0.67,1.04)$ & $1.08(0.84,1.37)$ \\
\hline Down hearted & $35(4.1)$ & $83(5.1)$ & $41(5.1)$ & 0.47 & $1.35(0.92,1.96)$ & $1.38(0.75,2.51)$ \\
\hline Tiredness & $63(7.7)$ & $138(9.0)$ & $112(14.9)$ & $<0.001$ & $1.22(0.90,1.65)$ & $2.20(1.67,2.90)^{\ddagger}$ \\
\hline Worn out & $44(5.2)$ & 79 (4.9) & $65(8.1)$ & $<0.001$ & $0.99(0.73,1.34)$ & $1.73(1.25,2.40)^{\dagger}$ \\
\hline Nervousness & $55(6.4)$ & $96(5.9)$ & $50(6.2)$ & 0.88 & $0.98(0.74,1.31)$ & $1.03(0.90,1.18)$ \\
\hline Energetic & $100(11.7)$ & $148(9.2)$ & 130 (16.2) & $<0.001$ & $0.75(0.50,1.13)$ & $1.49(1.09,2.04)^{*}$ \\
\hline Irritability & $27(3.1)$ & $38(2.3)$ & $30(3.7)$ & 0.15 & $0.77(0.50,1.19)$ & $1.22(0.70,2.11)$ \\
\hline Loss of interest & $12(1.4)$ & $39(2.4)$ & 26 (3.2) & 0.05 & $1.89(0.56,6.36)$ & $2.68(1.11,6.46)^{*}$ \\
\hline Loss of concentration & $41(4.7)$ & $92(5.7)$ & $43(5.3)$ & 0.61 & $1.13(0.74,1.72)$ & $1.07(0.67,1.73)$ \\
\hline Change in sleep & $97(11.2)$ & $214(13.2)$ & $124(15.4)$ & 0.04 & $1.21(0.91,1.59)$ & $1.45(1.03,2.05)^{*}$ \\
\hline Loss of energy & $43(5.0)$ & $82(5.1)$ & $64(7.9)$ & 0.01 & $1.05(0.74,1.51)$ & $1.80(1.21,2.66)^{\dagger}$ \\
\hline Fatigue & $42(4.8)$ & $83(5.1)$ & $60(7.4)$ & 0.04 & $1.05(0.74,1.51)$ & $1.80(1.21,2.66)^{\dagger}$ \\
\hline Sadness & $36(4.2)$ & $70(4.3)$ & $33(4.1)$ & 0.96 & $1.10(0.68,1.79)$ & $1.07(0.62,1.83)$ \\
\hline Worthless & $20(2.3)$ & $33(2.0)$ & $25(3.1)$ & 0.27 & $0.88(0.49,1.60)$ & $1.44(0.92,2.26)$ \\
\hline$\geq 1$ impaired psychological function & $263(33.1)$ & $547(36.1)$ & $314(42.8)$ & $<0.001$ & $1.15(0.92,1.44)$ & $1.56(1.20,2.03)^{\dagger}$ \\
\hline$\geq 2$ impaired psychological function & $131(16.5)$ & $262(17.3)$ & $175(23.9)$ & $<0.001$ & $1.11(0.88,1.40)$ & $1.77(1.30,2.42)^{\ddagger}$ \\
\hline$\geq 3$ impaired psychological function & $82(10.3)$ & $156(10.3)$ & $108(14.7)$ & 0.004 & $1.06(0.79,1.42)$ & $1.76(1.13,2.76)^{*}$ \\
\hline \multicolumn{7}{|l|}{ Sexual function } \\
\hline Low morning erections & $299(35.6)$ & $614(38.7)$ & $350(44.5)$ & $<0.001$ & $0.99(0.75,1.30)$ & $1.32(0.99,1.77)$ \\
\hline Erectile dysfunction & $206(24.8)$ & 470 (30.2) & $286(36.7)$ & $<0.001$ & $1.15(0.84,1.57)$ & $1.77(1.39,2.25)^{\ddagger}$ \\
\hline Low frequency of sexual thoughts & $228(26.8)$ & $435(27.4)$ & $227(28.8)$ & 0.66 & $0.84(0.70,1.01)$ & $0.92(0.76,1.12)$ \\
\hline Low sexual desire & $165(19.4)$ & $351(22.1)$ & $195(24.7)$ & 0.04 & $1.03(0.83,1.28)$ & $1.24(0.92,1.67)$ \\
\hline Overall sexual satisfaction & $238(28.7)$ & $405(26.0)$ & $224(28.6)$ & 0.24 & $0.86(0.77,0.96)^{\dagger}$ & $0.98(0.86,1.11)$ \\
\hline$\geq 1$ impaired sexual function & $512(63.7)$ & $955(63.6)$ & $530(71.0)$ & 0.001 & $0.84(0.72,0.99)^{\star}$ & $1.20(0.98,1.46)$ \\
\hline$\geq 2$ impaired sexual function & $278(34.6)$ & $557(37.1)$ & $300(40.2)$ & 0.075 & $0.85(0.64,1.14)$ & $1.21(0.93,1.56)$ \\
\hline$\geq 3$ impaired sexual function & $153(19.0)$ & 335 (22.3) & $201(26.9)$ & 0.001 & $0.90(0.61,1.34)$ & $1.59(1.10,2.29)^{*}$ \\
\hline
\end{tabular}

${ }^{\star} P<0.05,{ }^{\dagger} P<0.01,{ }^{\ddagger} P<0.001$.

${ }^{a}$ Multivariable logistic regression adjusted for age, smoking status, alcohol intake and centre (reference group: $\mathrm{BMI}<25 \mathrm{~kg} / \mathrm{m}^{2}$ ).

${ }^{\mathrm{b}} P$ values for $\chi^{2}$ test of independence.

impaired physical function (OR 2.67; CI: 2.07-3.45, $P<0.001)$, at least one symptom of impaired psychological function (OR 1.48; CI: 1.14-1.90, $P<0.01)$ and at least one symptom of impaired sexual function (OR 1.45; CI: $1.14-1.85, P<0.01)$. These health impairments persisted in men with BMI $<30 \mathrm{~kg} / \mathrm{m}^{2}$ and WC $\geq 102 \mathrm{~cm}$. By contrast, men with BMI $\geq 30 \mathrm{~kg} / \mathrm{m}^{2}$ and WC $<102 \mathrm{~cm}$ generally did not show significant association with the above health impairments except for impaired psychological function (and low sexual satisfaction). Further analysis revealed that men with
BMI $\geq 30 \mathrm{~kg} / \mathrm{m}^{2}$ and $W C \geq 102 \mathrm{~cm}$ were at even greater likelihood of having a composite of two or more and three or more symptoms compared with those with BMI $<30 \mathrm{~kg} / \mathrm{m}^{2}$ and WC $<102 \mathrm{~cm}$ (Table 4).

The areas under the ROC curves in the prediction of three or more symptoms of physical, psychological and sexual dysfunction respectively, were $0.60,0.55$ and 0.55 by BMI and were $0.64,0.58$ and 0.60 by WC. Adding BMI to WC in the regression model did not change the power of prediction (areas under the ROC curves $0.65,0.58$ and 0.60 respectively). 
Table 3 Prevalence and odds ratios to estimate the risk of symptoms from three domains of physical function (Short Form-36, SF-36), psychological function (SF-36 and Beck's Depression Inventory (BDI)) and sexual symptoms (European Male Ageing Study sexual function questionnaire, EMAS-SFQ) in different categories of waist circumference (WC).

\begin{tabular}{|c|c|c|c|c|c|c|}
\hline & \multicolumn{3}{|c|}{ WC $(\mathrm{cm} ; n(\%))$} & \multirow[b]{2}{*}{$\chi^{2}$ test $^{b}$} & \multicolumn{2}{|c|}{ WC $(\mathrm{cm} ; \text { OR }(95 \% \mathrm{Cl}))^{\mathrm{a}}$} \\
\hline & $<94$ & $\geq 94$ and $<102$ & $\geq 102$ & & $\geq 94$ and $<102$ & $\geq 102$ \\
\hline \multicolumn{7}{|l|}{ Physical function } \\
\hline Unable to do vigorous activity & $198(17.5)$ & $213(21.3)$ & $412(35.5)$ & $<0.001$ & $1.14(0.91,1.42)$ & $2.26(1.96,2.62)^{\ddagger}$ \\
\hline Unable to do moderate activity & $26(2.3)$ & $23(2.3)$ & $59(5.1)^{\prime}$ & $<0.001$ & $0.82(0.41,1.65)$ & $1.71(1.14,2.57)^{\dagger}$ \\
\hline Unable to carry heavy weights & $26(2.3)$ & $23(2.3)$ & $51(4.4)$ & $<0.001$ & $0.85(0.59,1.23)$ & $1.59(1.05,2.41)^{*}$ \\
\hline Unable to climb one flight of stairs & $16(1.4)$ & $10(1.0)$ & $37(3.2)$ & $<0.001$ & $0.64(0.30,1.38)$ & $1.84(1.27,2.64)^{\dagger}$ \\
\hline Unable to climb several flights of stairs & $50(4.4)$ & $56(5.6)$ & $148(12.7)$ & $<0.001$ & $1.15(0.74,1.79)$ & $2.71(2.02,3.64)^{\ddagger}$ \\
\hline Unable to bend & $41(3.6)$ & $46(4.6)$ & $127(10.9)$ & $<0.001$ & $1.10(0.70,1.73)$ & $2.71(1.79,4.11)^{\ddagger}$ \\
\hline Unable to feeding yourself & $12(1.1)$ & $10(1.0)$ & $23(2.0)$ & 0.08 & $0.89(0.43,1.85)$ & $1.54(0.89,2.67)$ \\
\hline Unable to rise from a chair & $11(1.0)$ & $9(0.9)$ & $20(1.7)$ & 0.15 & $0.73(0.23,2.34)$ & $1.44(0.87,2.37)$ \\
\hline Unable to walk in your home & $11(1.0)$ & $7(0.7)$ & $12(1.0)$ & 0.69 & $0.56(0.26,1.21)$ & $0.90(0.45,1.80)$ \\
\hline Unable to bath yourself & $11(1.0)$ & $10(1.0)$ & $19(1.6)$ & 0.26 & $0.83(0.40,1.72)$ & $1.38(0.71,2.68)$ \\
\hline Unable to walk more than $1 \mathrm{~km}$ & 49 (4.3) & $53(5.3)$ & $145(12.5)$ & $<0.001$ & $1.11(0.80,1.52)$ & $2.73(2.10,3.55)^{\ddagger}$ \\
\hline Reduced work & 49 (4.3) & $38(3.8)$ & $97(8.3)$ & $<0.001$ & $0.83(0.60,1.15)$ & $1.87(1.40,2.50)^{\ddagger}$ \\
\hline$\geq 1$ impaired physical function & $224(20.0)$ & $226(23.3)$ & $461(40.6)$ & $<0.001$ & $1.10(0.89,1.36)$ & $2.45(2.15,2.78)^{\ddagger}$ \\
\hline$\geq 2$ impaired physical function & $90(8.0)$ & $93(9.6)$ & $234(20.6)$ & $<0.001$ & $1.11(0.86,1.42)$ & $3.13(2.58,3.79)^{\ddagger}$ \\
\hline$\geq 3$ impaired physical function & $58(5.2)$ & $48(5.0)$ & $141(12.4)$ & $<0.001$ & $0.87(0.62,1.22)$ & $2.91(2.06,4.12)^{\ddagger}$ \\
\hline \multicolumn{7}{|l|}{ Psychological function } \\
\hline Down in the dumps & $31(2.8)$ & $24(2.4)$ & $41(3.5)$ & 0.28 & $0.81(0.49,1.33)$ & $1.24(0.74,2.10)$ \\
\hline Full of life & $108(9.6)$ & $97(9.7)$ & $142(12.3)$ & 0.07 & $0.93(0.83,1.06)$ & $1.20(0.97,1.49)$ \\
\hline Down hearted & $53(4.7)$ & $45(4.5)$ & $63(5.5)$ & 0.56 & $0.95(0.62,1.45)$ & $1.12(0.91,1.37)$ \\
\hline Tiredness & $83(7.7)$ & $78(8.2)$ & $155(14.2)$ & $<0.001$ & $1.08(0.66,1.76)$ & $1.96(1.55,2.47)^{\ddagger}$ \\
\hline Worn out & $54(4.8)$ & $46(4.6)$ & $90(7.8)^{\prime}$ & $<0.001$ & $0.96(0.59,1.58)$ & $1.63(1.27,2.09)^{\ddagger}$ \\
\hline Nervo & $66(5.9)$ & $58(5.8)$ & 79 (6.8) & 0.55 & $1.00(0.62,1.62)$ & $1.21(0.86,1.70)$ \\
\hline Energetic & $104(9.3)$ & $98(9.8)$ & $178(15.4)$ & $<0.001$ & $1.04(0.72,1.49)$ & $1.69(1.20,2.37)^{\dagger}$ \\
\hline Irritability & $30(2.6)$ & $28(2.8)$ & $37(3.2)$ & 0.74 & $1.07(0.63,1.81)$ & $1.22(0.80,1.86)$ \\
\hline Loss of interest & $13(1.1)$ & $20(2.0)$ & $43(3.7)$ & $<0.001$ & $1.74(0.73,4.17)$ & $3.04(1.66,5.59)^{\ddagger}$ \\
\hline Loss of concentration & $50(4.4)$ & $45(4.5)$ & $82(7.0)$ & 0.01 & $0.94(0.58,1.55)$ & $1.44(0.97,2.16)$ \\
\hline Change in sleep & $126(11.1)$ & $131(13.1)$ & $182(15.6)$ & 0.01 & $1.19(0.93,1.54)$ & $1.42(0.99,2.03)$ \\
\hline Loss of energy & $54(4.8)$ & $33(3.3)$ & $104(8.9)$ & $<0.001$ & $0.68(0.35,1.31)$ & $1.87(1.35,2.59)^{\ddagger}$ \\
\hline Fatigue & $56(4.9)$ & $46(4.6)$ & $86(7.4)$ & 0.01 & $0.68(0.35,1.31)$ & $1.87(1.35,2.59)^{\ddagger}$ \\
\hline Sadness & $41(3.6)$ & $46(4.6)$ & $53(4.6)$ & 0.43 & $1.29(0.78,2.12)$ & $1.28(0.78,2.10)$ \\
\hline Worthless & $27(2.4)$ & $18(1.8)$ & $33(2.8)$ & 0.28 & $0.77(0.46,1.28)$ & $1.13(0.73,1.75)$ \\
\hline aired psychological function & $348(33.0)$ & $324(34.9)$ & $458(42.8)$ & $<0.001$ & $1.05(0.83,1.32)$ & $1.44(1.22,1.71)^{\ddagger}$ \\
\hline$\geq 2$ impaired psychological function & $157(14.9)$ & 155 (16.7) & $261(24.4)$ & $<0.001$ & $1.11(0.88,1.39)$ & $1.78(1.42,2.24)^{\ddagger}$ \\
\hline$\geq 3$ impaired psychological function & $98(9.3)$ & $89(9.6)$ & $162(15.1)$ & $<0.001$ & $1.03(0.76,1.39)$ & $1.78(1.28,2.48)^{\dagger}$ \\
\hline \multicolumn{7}{|l|}{ Sexual function } \\
\hline Low morning erections & $371(33.5)$ & 389 (39.4) & $509(45.2)$ & $<0.001$ & $1.09(0.88,1.35)$ & $1.33(1.06,1.67)^{\star}$ \\
\hline Erectile dysfunction & $258(23.5)$ & $280(29.0)$ & $426(38.3)$ & $<0.001$ & $1.32(0.99,1.75)$ & $1.73(1.50,1.98)^{\ddagger}$ \\
\hline Low frequency of sexual thoughts & $264(23.6)$ & $272(27.7)$ & $355(31.3)$ & $<0.001$ & $1.04(0.80,1.34)$ & $1.06(0.84,1.35)$ \\
\hline Low sexual desire & $208(18.6)$ & $194(19.7)$ & $310(27.4)$ & $<0.001$ & $1.41(1.10,1.81)^{\dagger}$ & $1.31(0.96,1.79)$ \\
\hline Overall sexual satisfaction & $290(26.7)$ & $257(26.4)$ & $323(28.9)$ & 0.37 & $1.02(0.83,1.27)$ & $1.14(0.97,1.33)$ \\
\hline$\geq 1$ impaired sexual function & 635 (59.9) & $590(63.5)$ & 777 (72.8) & $<0.001$ & $1.28(1.12,1.46)^{\ddagger}$ & $1.45(1.14,1.85)^{\dagger}$ \\
\hline$\geq 2$ impaired sexual function & $339(32.0)$ & $338(36.4)$ & $460(43.1)$ & $<0.001$ & $1.37(1.00,1.88)^{*}$ & $1.48(1.13,1.94)^{\dagger}$ \\
\hline$\geq 3$ impaired sexual function & $188(17.7)$ & $200(21.5)$ & $303(28.4)$ & $<0.001$ & $1.40(0.90,2.19)$ & $1.87(1.28,2.72)^{\dagger}$ \\
\hline
\end{tabular}

${ }^{*} P<0.05,{ }^{\dagger} P<0.01,{ }^{\ddagger} P<0.001$.

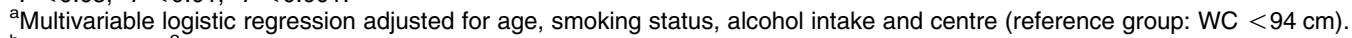

${ }^{\mathrm{b}} P$ values for $\chi^{2}$ test of independence.

\section{Discussion}

This study has shown that obese men, with high BMI and/or high WC, are at greater risk for a range of symptoms encompassing physical, psychological and sexual domains that can diminish QoL independent of age and lifestyle factors. A large WC plays a key role as a predictor of poor QoL, as evident by the multidomain symptomatic functional impairments even in men who are not considered to be 'obese' based on BMI $\geq 30 \mathrm{~kg} / \mathrm{m}^{2}$. This is likely to be because in subjects with similar BMI, variations in WC also reflect differences in intra-abdominal fat mass. High BMI has been shown to associate with erectile dysfunction in previous cross-sectional and prospective studies $(27,28)$, and WC has been shown to be a better predictor of erectile dysfunction than BMI $(29,30)$. These findings are particularly important because the prevalence of obesity indicated by high BMI, which is equally matched by that of large WC, continues to rise worldwide, consuming some $10 \%$ of health care resources $(3,9$, 31-34). This further strengthens the justification for 
public health preventative measures in combating the rising prevalence of obesity, providing additional incentivisation for individuals to improve QoL. Weight management should target younger age groups when fat accumulation is most rapid (13), particularly those
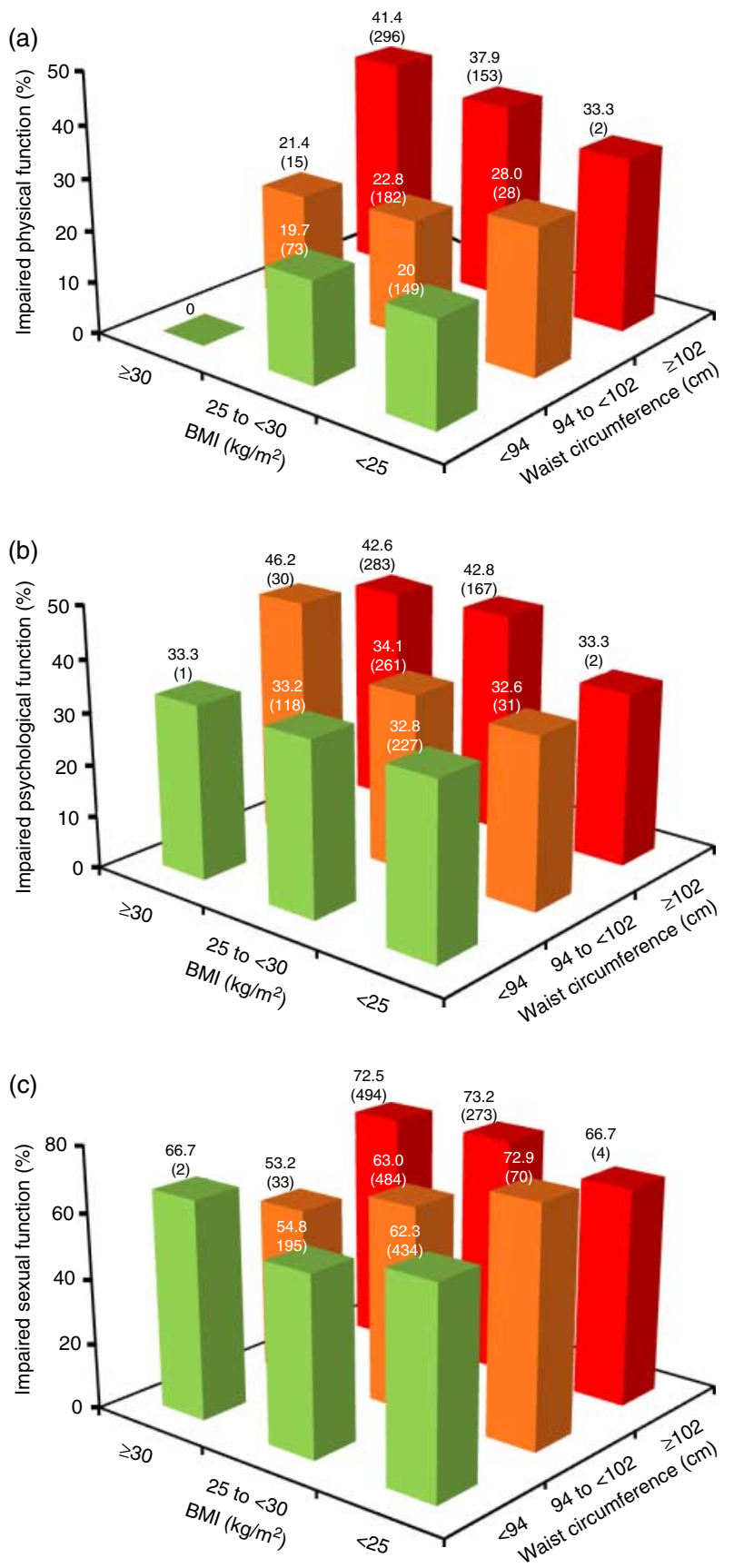

Figure 1 Proportions (numbers in brackets) of men with at least one symptom of impaired physical function (a), and at least one symptom of impaired psychological function (b) and at least one symptom of impaired sexual function (c) in different categories according to the degrees of their adiposity assessed by BMI and by waist circumference. Full colour version of this figure available via http://dx.doi.org/10.1530/EJE-10-1129. who are approaching $\mathrm{WC}$ action level $1(\mathrm{WC}=94 \mathrm{~cm})$ (25) and high-risk groups such as those with strong family history of obesity and related complications more commonly observed in ethnic groups. The public is now increasingly informed of obesity-related health risks through education and health promotion programmes but the people at highest risk are those in lower socioeconomic/education levels (8).

In epidemiological studies, BMI is widely used as a proxy for body fatness, and it is also influenced by muscle mass. WC also correlates highly with total body fat and with intra-abdominal fat when the relationship is not overwhelmed by variations in total body fat (35). WC is associated with a range of health consequences including hypertension, diabetes mellitus, coronary heart disease, respiratory disease, musculoskeletal disorders, cancers and premature death (36-39). The initial observations in cross-sectional studies have all been confirmed in longitudinal cohort studies (40-42). WC generally shows less stronger associations with health outcomes than BMI, possibly because it is not influenced by variations in muscle mass. Greater muscle mass is likely to reflect better health and greater physical activity but tends to elevate BMI in certain individuals. The confounding effect of variations in muscle mass on BMI is likely to be particularly important in studies involving ageing where sarcopenia may increasingly influence BMI relationships.

The main strengths of our study are that it is based on a large population-based sample that used uniform methods to assess depressed mood, physical activity and physical function. Methodological limitations inherent to the EMAS study have previously been described in detail (21), although a number of specific factors need to be considered in interpreting the results presented here. The overall response rate for participation in the study was $43 \%$. Those who participated may have differed with respect to symptoms and anthropometric measures from those who did not participate, thus some caution is needed in interpreting the data. The main findings, however, were based on an internal comparison of responders, and therefore any selection factors were unlikely to have had any important effect on these data. The results were obtained from predominantly Caucasian European men and should be extrapolated beyond this setting with care. The findings from this cross-sectional study cannot be assumed to be causal because poor health per se can lead to obesity and central fat accumulation, but a causal relationship is at least very plausible, as supported by the longitudinal studies cited earlier (37, 38). In this study, categorisation of BMI and WC was based on conventional cut-offs used for clinical and health promotion purposes worldwide, as defined by the World Health Organization (43) for BMI (25 and $30 \mathrm{~kg} / \mathrm{m}^{2}$ ) and by the National Cholesterol Education Program (26), as originally proposed by Lean et al. (25) for WC action levels (94 and $102 \mathrm{~cm}$ ) respectively. 
Table 4 Odds ratios to estimate the risk of impaired physical function (Short Form-36, SF-36), psychological dysfunction (SF-36 and Beck's Depression Inventory (BDI)) and sexual dysfunction (European Male Ageing Study sexual function questionnaire, EMAS-SFQ) in men with either high body mass index (BMI) or high waist circumference (WC) or both of these indices of adverse adiposity.

\begin{tabular}{|c|c|c|c|}
\hline & \multicolumn{3}{|c|}{ OR $(95 \% \mathrm{CI})^{\mathrm{a}}$} \\
\hline & $\begin{array}{l}\mathrm{BMI} \geq 30 \mathrm{~kg} / \mathrm{m}^{2} \\
\text { and } \mathrm{WC} \geq 102 \mathrm{~cm}\end{array}$ & $\begin{array}{l}\mathrm{BMl}<30 \mathrm{~kg} / \mathrm{m}^{2} \\
\text { and } \mathrm{WC} \geq 102 \mathrm{~cm}\end{array}$ & $\begin{array}{l}\mathrm{BMI} \geq 30 \mathrm{~kg} / \mathrm{m}^{2} \\
\text { and } \mathrm{WC}<102 \mathrm{~cm}\end{array}$ \\
\hline \multicolumn{4}{|l|}{ Physical function } \\
\hline Unable to do vigorous activity & $2.33(1.73,3.14)^{\ddagger}$ & $1.78(1.42,2.22)^{\ddagger}$ & $1.41(0.61,3.22)$ \\
\hline Unable to do moderate activity & $1.61(1.25,2.08)^{\ddagger}$ & $1.78(1.06,2.99)^{\star}$ & NA \\
\hline Unable to carry heavy weights & $1.91(1.18,3.10)^{\dagger}$ & $0.95(0.58,1.56)$ & NA \\
\hline Unable to climb one flight of stairs & $1.86(0.89,3.90)$ & $2.26(1.27,4.01)^{\dagger}$ & $1.44(0.27,7.65)$ \\
\hline Unable to climb several flights of stairs & $2.81(2.05,3.85)^{\ddagger}$ & $1.94(1.13,3.34)^{\star}$ & $1.14(0.54,2.38)$ \\
\hline Unable to bend & $3.18(2.35,4.28)^{\ddagger}$ & $1.74(1.08,2.81)^{\star}$ & $1.34(0.53,3.40)$ \\
\hline Unable to feeding yourself & $1.97(1.11,3.51)^{\star}$ & $0.98(0.39,2.45)$ & NA \\
\hline Unable to rise from a chair & $1.74(0.97,3.12)$ & $1.26(0.57,2.78)$ & NA \\
\hline Unable to walk in your home & $0.98(0.63,1.53)$ & $1.02(0.37,2.83)$ & NA \\
\hline Unable to bath yourself & $1.17(0.59,2.32)$ & $1.96(0.83,4.63)$ & NA \\
\hline Unable to walk more than $1 \mathrm{~km}$ & $2.73(1.87,4.00)^{\ddagger}$ & $1.98(1.47,2.69)^{\ddagger}$ & NA \\
\hline Reduced work & $2.46(1.47,4.10)^{\dagger}$ & $1.20(0.83,1.72)$ & $0.39(0.07,2.11)$ \\
\hline$\geq 1$ impaired physical function & $2.67(2.07,3.45)^{\ddagger}$ & $1.80(1.53,2.13)^{\ddagger}$ & $1.30(0.56,3.03)$ \\
\hline$\geq 2$ impaired physical function & $3.38(2.36,4.83)^{\ddagger}$ & $2.21(1.73,2.81)^{\ddagger}$ & $0.91(0.51,1.64)$ \\
\hline$\geq 3$ impaired physical function & $3.79(2.59,5.56)^{\ddagger}$ & $1.87(1.23,2.84)^{\dagger}$ & $0.39(0.09,1.64)$ \\
\hline \multicolumn{4}{|l|}{ Psychological function } \\
\hline Down in the dumps & $1.51(1.08,2.10)^{\star}$ & $0.86(0.39,1.90)$ & $0.61(0.07,5.73)$ \\
\hline Full of life & $1.27(0.93,1.72)$ & $1.12(0.82,1.54)$ & $0.98(0.48,1.99)$ \\
\hline Down hearted & $1.17(0.80,1.72)$ & $1.03(0.68,1.55)$ & $0.68(0.17,2.70)$ \\
\hline Tiredness & $2.14(1.52,3.00)^{\ddagger}$ & $1.65(1.15,2.36)^{\dagger}$ & $2.23(1.24,4.00)^{\dagger}$ \\
\hline Worn out & $1.89(1.27,2.81)^{\dagger}$ & $1.45(1.08,1.94)^{\star}$ & $2.07(0.76,5.60)$ \\
\hline Nervousness & $1.12(0.83,1.50)$ & $1.25(0.92,1.71)$ & $0.75(0.23,2.39)$ \\
\hline Energetic & $1.93(1.52,2.44)^{\ddagger}$ & $1.30(0.88,1.91)$ & $1.58(0.95,2.64)$ \\
\hline Irritability & $1.42(0.82,2.44)$ & $0.70(0.42,1.14)$ & $0.99(0.22,4.46)$ \\
\hline Loss of interest & $2.25(1.67,3.03)^{\ddagger}$ & $2.09(1.32,3.32)^{\dagger}$ & NA \\
\hline Loss of concentration & $1.15(0.86,1.54)$ & $1.98(1.40,2.82)^{\ddagger}$ & $1.38(0.84,2.25)$ \\
\hline Change in sleep & $1.33(1.03,1.73)^{\star}$ & $1.19(0.76,1.87)$ & $1.25(0.67,2.35)$ \\
\hline Loss of energy & $2.24(1.70,2.96)^{\ddagger}$ & $1.94(1.22,3.07)^{\dagger}$ & NA \\
\hline Fatigue & $1.65(1.17,2.34)^{\dagger}$ & $0.98(0.67,1.45)$ & $0.30(0.06,1.52)$ \\
\hline Sadness & $1.06(0.67,1.66)$ & $1.12(0.68,1.84)$ & $0.73(0.20,2.68)$ \\
\hline Worthless & $1.60(1.03,2.48)^{\star}$ & $0.53(0.18,1.58)$ & NA \\
\hline$\geq 1$ impaired psychological function & $1.48(1.14,1.90)^{\dagger}$ & $1.35(1.12,1.64)^{\dagger}$ & $1.82(1.30,2.53)^{\ddagger}$ \\
\hline$\geq 2$ impaired psychological function & $1.81(1.27,2.57)^{\dagger}$ & $1.52(1.13,2.05)^{\dagger}$ & $1.72(1.24,2.38)^{\dagger}$ \\
\hline$\geq 3$ impaired psychological function & $1.88(1.21,2.93)^{\dagger}$ & $1.54(1.03,2.30)^{\star}$ & $1.53(0.73,3.20)$ \\
\hline \multicolumn{4}{|l|}{ Sexual function } \\
\hline Low morning erections & $1.33(1.06,1.67)^{*}$ & $1.09(0.88,1.35)$ & $1.63(0.94,2.81)$ \\
\hline Erectile dysfunction & $1.73(1.50,1.98)^{\ddagger}$ & $1.32(0.99,1.75)$ & $1.39(0.74,2.60)$ \\
\hline Low frequency of sexual thoughts & $1.06(0.84,1.35)$ & $1.04(0.80,1.34)$ & $0.70(0.40,1.22)$ \\
\hline Low sexual desire & $1.31(0.96,1.79)$ & $1.41(1.10,1.81)^{\dagger}$ & $1.17(0.50,2.71)$ \\
\hline Overall sexual satisfaction & $1.14(0.97,1.33)$ & $1.02(0.83,1.27)$ & $0.61(0.39,0.96)^{*}$ \\
\hline$\geq 1$ impaired sexual function & $1.45(1.14,1.85)^{\dagger}$ & $1.28(1.12,1.46)^{\ddagger}$ & $0.92(0.57,1.50)$ \\
\hline$\geq 2$ impaired sexual function & $1.48(1.13,1.94)^{\dagger}$ & $1.37(1.00,1.88)^{\star}$ & $0.94(0.65,1.37)$ \\
\hline$\geq 3$ impaired sexual function & $1.87(1.28,2.72)^{\dagger}$ & $1.40(0.90,2.19)$ & $1.13(0.69,1.86)$ \\
\hline
\end{tabular}

${ }^{\star} P<0.05,{ }^{\dagger} P<0.01,{ }^{\ddagger} P<0.001$. NA, no data in this category.

a Multivariable logistic regression adjusted for age, smoking status, alcohol intake and centre (reference group: $\mathrm{BMl}<30 \mathrm{~kg} / \mathrm{m}^{2}$ and WC $<102 \mathrm{~cm})$.

Application of other statistical cut-off levels such as tertiles of BMI and WC was examined and did not change their patterns of relationships with symptoms of impaired QoL. ROC analysis showed that the power of prediction by indices of adiposity was similar to previous studies (44). We decided that the results should be presented without adjusting for co-morbidity as related to obesity. Analysis with adjustments for co-morbidities showed no significant change in the relationships between adiposity and symptoms of ageing, which indicates that the impact of individual co-morbidities is relatively slight. By using the outcome 'at least one symptom of' this analysis has assumed equal importance of all the symptoms. This is unlikely to be true for any individual. It is also possible that certain specific symptoms could dominate the associations described. Men with high indices of adiposity were shown to have exaggerated risk of having composites of two or more 
and three or more symptoms of impaired functions. It is of interest that indices of adiposity tend to associate more strongly with the 'physical' items (e.g. tiredness or worn out) of the psychological domain than the 'emotional' items (e.g. loss of interest or change in sleep). The present EMAS data did not show correlations between age and BMI or WC probably because the rates of increases in adiposity are most rapid in younger adults and rather less so up to age 60 years, and also in part, because of reduction in muscle mass from agerelated muscle atrophy.

In conclusion, many of the complaints and health problems commonly associated with impaired QoL in older men are accounted for by increased body fat, including those with large waists who are not considered to be 'obese' according to BMI. There is a substantial increase in symptoms as people range from BMI $<25$ to $\geq 25-30$ categories. WC is a more telling physical measure: lower WC appears to be protective against these health complications even in the presence of high BMI. Health promotion should focus on prevention of excess adult fat accumulation, to reduce burdens of ill health, and weight management should focus on improving the impaired QoL of overweight and obese people.

\section{Supplementary data}

This is linked to the online version of the paper at http://dx.doi.org/10. 1530/EJE-10-1129.

\section{Declaration of interest}

The authors declare that there is no conflict of interest that could be perceived as prejudicing the impartiality of the research reported.

\section{Funding}

The European Male Ageing Study (EMAS) is funded by the Commission of the European Communities Fifth Framework Programme 'Quality of Life and Management of Living Resources' Grant QLK6-CT-2001-00258.

\section{Acknowledgements}

The authors wish to thank the participants in the eight countries and research/nursing staff in the eight centres: C Pott (Manchester), E Wouters (Leuven), M Nilsson (Malmö), M del Mar Fernandez (Santiago de Compostela), M Jedrzejowska (Lodz), H-M Tabo (Tartu) and A Heredi (Szeged) for their meticulous data collection and C Moseley (Manchester) for data entry and project co-ordination. $S$ Boonen is the senior clinical investigator of the Fund for Scientific research (FWO-Vlaanderen) and holder of the Leuven University Chair in Gerontology and Geriatrics.

\section{EMAS Group}

Florence (Gianni Forti, Luisa Petrone, Giovanni Corona); Leuven (Dirk Vanderschueren, Steven Boonen, Herman Borghs); Lodz (Krzysztof Kula, Jolanta Slowikowska-Hilczer, Renata WalczakJedrzejowska); London (Ilpo Huhtaniemi); Malmö (Aleksander
Giwercman); Manchester (Frederick Wu, Alan Silman, Terence O'Neill, Joseph Finn, Philip Steer, Abdelouahid Tajar, David Lee, Stephen Pye); Santiago (Felipe F Casanueva, Mary Lage); Szeged (György Bartfai, Imre Földesi, Imre Fejes); Tartu (Margus Punab, Paul Korrovitz); Turku (Min Jiang).

\section{References}

1 Visscher TL \& Seidell JC. The public health impact of obesity. Annual Review of Public Health 200122 355-375. (doi:10.1146/ annurev.publhealth.22.1.355)

2 Berghöfer A, Pischon T, Reinhold T, Apovian CM, Sharma AM \& Willich SN. Obesity prevalence from a European perspective: a systematic review. BMC Public Health 20088 200. (doi:10. 1186/1471-2458-8-200)

3 Cameron AJ, Welborn TA, Zimmet PZ, Dunstan DW, Owen N, Salmon J, Dalton M, Jolley D \& Shaw JE. Overweight and obesity in Australia: the 1999-2000 Australian diabetes, obesity and lifestyle study (AusDiab). Medical Journal of Australia $2003 \mathbf{1 7 8}$ $427-432$

4 Flegal KM, Carroll MD, Ogden CL \& Johnson CL. Prevalence and trends in obesity among U.S. adults, 1999-2000. Journal of the American Medical Association 2002288 1723-1727. (doi:10. 1001/jama.288.14.1723)

5 Ogden CL, Carroll MD, Curtin LR, McDowell MA, Tabak CJ \& Flegal KM. Prevalence of overweight and obesity in the United States, 1999-2004. Journal of the American Medical Association 2006295 1549-1555. (doi:10.1001/jama.295.13.1549)

6 Flegal KM, Carroll MD, Ogden CL \& Curtin LR. Prevalence and trends in obesity among US adults, 1999-2008. Journal of the American Medical Association 2010303 235-241. (doi:10.1001/ jama.2009.2014)

7 Kumar BN, Meyer HE, Wandel M, Dalen I \& Holmboe-Ottesen G. Ethnic differences in obesity among immigrants from developing countries, in Oslo, Norway. International Journal of Obesity 200630 684-690. (doi:10.1038/sj.ijo.0803051)

8 Wang Y \& Beydoun MA. The obesity epidemic in the United States - gender, age, socioeconomic, racial/ethnic, and geographic characteristics: a systematic review and meta-regression analysis. Epidemiologic Reviews 200729 6-28. (doi:10.1093/epirev/ mxm007)

9 Ford ES \& Mokdad AH. Epidemiology of obesity in the western hemisphere. Journal of Clinical Endocrinology and Metabolism 2008 93 S1-S8. (doi:10.1210/jc.2008-1356)

10 Population Division of the Department of Economic and Social Affairs of the United Nations Secretariat. World Population Prospects: The 2006 Revision and World Urbanization Prospects: The 2005 Revision (http://esa.un.org/unpp).

11 Freedman DS, Khan LK, Serdula MK, Galuska DA \& Dietz WH. Trends and correlates of class 3 obesity in the united states from 1990 through 2000. Journal of the American Medical Association 2002288 1758-1761. (doi:10.1001/jama.288.14.1758)

12 Corbett J, Given L, Gray L, Leyland A, MacGregor A, Marryat L, Miller M \& Reid S. The Scottish Health Survey 2008, Volume 1. Scottish Government: Edinburgh; 2009 (www.scotland.gov.uk/ Resource/Doc/286063/0087159.pdf).

13 Ebrahimi-Mameghani M, Scott JA, Lean MEJ \& Burns CM. Changes in weight and waist circumference over 9 years in a Scottish population. European Journal of Clinical Nutrition $2008 \mathbf{6 2}$ 1208-1214. (doi:10.1038/sj.ejcn.1602839)

14 Hawn MT, Bian J, Leeth RR, Ritchie G, Allen N, Bland KI \& Vickers SM. Impact of obesity on resource utilization for general surgical procedures. Annals of Surgery 2005241 821-826. (doi:10.1097/01.sla.0000161044.20857.24)

15 Hagenmeyer E-G, von Lengerke T, Gothe H, Schiffhorst G \& Happich M. Impact of concomitant obesity on health care resource consumption in patients with diabetes. Häussler B. iHEA 2007 6th World Congress: Explorations in Health Economics Paper 2007. 
16 Akinnusi ME, Pineda LA \& El Solh AA. Effect of obesity on intensive care morbidity and mortality: a meta-analysis. Critical Care Medicine 200836 151-158. (doi:10.1097/01.CCM. $0000297885.60037 .6 \mathrm{E})$

17 Trogdon JG, Finkelstein EA, Hylands T, Dellea PS \& Kamal-Bahl SJ. Indirect costs of obesity: a review of the current literature. Obesity Reviews 20089 489-500. (doi:10.1111/j.1467-789X.2008. 00472.x)

18 The Counterweight Project Team. Impact of obesity on drug prescribing in primary care. British Journal of General Practice 2005 55 743-749.

19 Thorpe KE, Florence CS, Howard DH \& Joski P. The impact of obesity on rising medical spending. Health Affairs 2004 Suppl Web Exclusives W4-480-W4-486. (10.1377/hlthaff.W4.480)

20 Finkelstein EA, Trogdon JG, Cohen JW \& Dietz W. Annual medical spending attributable to obesity: payer- and service-specific estimates. Health Affairs 200928 W822-W831. (doi:10.1377/ hlthaff.28.5.w822)

21 Lee DM, O'Neill TW, Pye SR, Silman AJ, Finn JD, Pendleton N, Tajar A, Bartfai G, Casanueva F, Forti G, Giwercman A, Huhtaniemi IT, Kula K, Punab M, Boonen S, Vanderschueren D, Wu FC \& EMAS study group. The European Male Ageing Study (EMAS): design, methods and recruitment. International Journal of Andrology 200932 11-24. (doi:10.1111/j.1365-2605.2008.00879.x)

22 Ware JE, Kosinski M \& Keller SD. SF-36 Physical and Mental Summary Scales: a User's Manual. Boston, Massachusetts: The Health Institute, New England Medical Center, 1994.

23 Beck AT, Steer RA \& Brown GK. Manual for the Beck Depression Inventory-II. San Antonio, TX: Psychological Corporation, 1996.

24 O'Connor DB, Corona G, Forti G, Tajar A, Lee DM, Finn JD, Bartfai G, Boonen S, Casanueva FF, Giwercman A, Huhtaniemi IT, Kula K, O'Neill TW, Pendleton N, Punab M, Silman AJ, Vanderschueren D \& Wu FC. Assessment of sexual health in aging men in Europe: development and validation of the European Male Ageing Study sexual function questionnaire. Journal of Sexual Medicine 20085 1374-1385. (doi:10.1111/j.1743-6109.2008.00781.x)

25 Lean ME, Han TS \& Morrison CE. Waist circumference as a measure for indicating need for weight management. BMJ 1995 311 158-161.

26 National Cholesterol Education Program (NCEP) Expert Panel on Detection, Evaluation, and Treatment of High Blood Cholesterol in Adults (Adult Treatment Panel III). Third Report of the National Cholesterol Education Program (NCEP) Expert Panel on Detection, Evaluation, and Treatment of High Blood Cholesterol in Adults (Adult Treatment Panel III) final report. Circulation $2002 \mathbf{1 0 6}$ 3143-3421.

27 Larsen SH, Wagner G \& Heitmann BL. Sexual function and obesity. International Journal of Obesity 200731 1189-1198. (doi:10. 1038/sj.ijo.0803604)

28 Bacon CG, Mittleman MA, Kawachi I, Giovannucci E, Glasser DB \& Rimm EB. A prospective study of risk factors for erectile dysfunction. Journal of Urology $2006 \quad 176$ 217-221. (doi:10. 1016/S0022-5347(06)00589-1)

29 Janiszewski PM, Janssen I \& Ross R. Abdominal obesity and physical inactivity are associated with erectile dysfunction independent of body mass index. Journal of Sexual Medicine 2009 6 1990-1998. (doi:10.1111/j.1743-6109.2009.01302.x)

30 Riedner CE, Rhoden EL, Ribeiro EP \& Fuchs SC. Central obesity is an independent predictor of erectile dysfunction in older men. Journal of Urology $2006 \mathbf{1 7 6}$ 1519-1523. (doi:10.1016/j.juro. 2006.06.049)

31 Ford ES, Mokdad AH \& Giles WH. Trends in waist circumference among US adults. Obesity Research 200311 1223-1231. (doi:10. 1038/oby.2003.168)
32 Okosun IS, Choi ST, Boltri JM, Parish DC, Chandra KM, Dever GE \& Lucas A. Trends of abdominal adiposity in white, black, and Mexican-American adults, 1988 to 2000. Obesity Research 2003 11 1010-1017. (doi:10.1038/oby.2003.139)

33 Okosun IS, Chandra KM, Boev A, Boltri JM, Choi ST, Parish DC \& Dever GE. Abdominal adiposity in U.S. adults: prevalence and trends, 1960-2000. Preventive Medicine 200439 197-206. (doi:10.1016/j.ypmed.2004.01.023)

$34 \mathrm{Li} \mathrm{C}$, Ford ES, McGuire LC \& Mokdad AH. Increasing trends in waist circumference and abdominal obesity among US adults. Obesity 200715 216-224. (doi:10.1038/oby.2007.505)

35 Han TS, McNeill G, Seidell JC \& Lean ME. Predicting intraabdominal fatness from anthropometric measures: the influence of stature. International Journal of Obesity 199721 587-593. (doi:10. 1038/sj.ijo.0800446)

36 Pouliot MC, Després JP, Lemieux S, Moorjani S, Bouchard C, Tremblay A, Nadeau A \& Lupien PJ. Waist circumference and abdominal sagittal diameter: best simple anthropometric indexes of abdominal visceral adipose tissue accumulation and related cardiovascular risk in men and women. American Journal of Cardiology 199473 460-468. (doi:10.1016/0002-9149(94)90676-9)

37 Han TS, van Leer EM, Seidell JC \& Lean ME. Waist circumference action levels in the identification of cardiovascular risk factors: prevalence study in a random sample. BMJ 1995311 1401-1405.

38 Lean ME, Han TS \& Seidell JC. Impairment of health and quality of life in people with large waist circumference. Lancet 1998351 853-856. (doi:10.1016/S0140-6736(97)10004-6)

39 Seidell JC. Waist circumference and waist/hip ratio in relation to all-cause mortality, cancer and sleep apnea. European Journal of Clinical Nutrition 2010 64 35-41. (doi:10.1038/ejcn.2009.71)

40 Balkau B, Picard P, Vol S, Fezeu L, Eschwège E \& DESIR Study Group. Consequences of change in waist circumference on cardiometabolic risk factors over 9 years: data from an Epidemiological Study on the Insulin Resistance Syndrome (DESIR). Diabetes Care 200730 1901-1903. (doi:10.2337/dc06-2542)

41 Pischon T, Boeing H, Hoffmann K, Bergmann M, Schulze MB, Overvad K, van der Schouw YT, Spencer E, Moons KG, Tjønneland A, Halkjaer J, Jensen MK, Stegger J, ClavelChapelon F, Boutron-Ruault MC, Chajes V, Linseisen J, Kaaks R, Trichopoulou A, Trichopoulos D, Bamia C, Sieri S, Palli D, Tumino R, Vineis P, Panico S, Peeters PH, May AM, Buenode-Mesquita HB, van Duijnhoven FJ, Hallmans G, Weinehall L, Manjer J, Hedblad B, Lund E, Agudo A, Arriola L, Barricarte A, Navarro C, Martinez C, Quirós JR, Key T, Bingham S, Khaw KT, Boffetta P, Jenab M, Ferrari P \& Riboli E. General and abdominal adiposity and risk of death in Europe. New England Journal of Medicine 2008359 2105-2120. (doi:10.1056/NEJMoa0801891)

42 Zhang C, Rexrode KM, van Dam RM, Li TY \& Hu FB. Abdominal obesity and the risk of all-cause, cardiovascular, and cancer mortality: sixteen years of follow-up in US women. Circulation 2008117 1658-1667. (doi:10.1161/CIRCULATIONAHA.107. 739714)

43 WHO Regional Office for Europe. Atlas of health in Europe 2nd edition 2008 (http://www.euro.who.int/pub).

44 Han TS, van Leer EM, Seidell JC \& Lean ME. Waist circumference as a screening tool for cardiovascular risk factors: evaluation of receiver operating characteristics (ROC). Obesity Research 19964 533-547.

Received 28 March 2011

Accepted 1 April 2011 